Setyo Purwoto, Teguh Purwanto, Luqmanul Hakim : Penjernihan Air Sungai Dengan Perlakuan Koagulasi, Filtrasi, Absorbsi dan Pertukaran Ion

\title{
PENJERNIHAN AIR SUNGAI DENGAN PERLAKUAN KOAGULASI, FILTRASI, ABSORBSI, DAN PERTUKARAN ION
}

\author{
Setyo Purwoto ${ }^{1)}$, Teguh Purwanto ${ }^{2)}$, Luqmanul Hakim ${ }^{3)}$ \\ ${ }^{1)}$ Program Studi Teknik Lingkungan, Fakultas Teknik Sipil dan Perencanaan \\ 2) Program Studi Ekonomi Akuntansi, Fakultas Ekonomi \\ ${ }^{3)}$ Program Studi Pendidikan Kepelatihan Olahraga, Fakultas Keguruan dan Ilmu Pendidikan \\ Universitas PGRI Adi Buana (UNIPA) Surabaya \\ Email : setyopurwoto.enviro@gmail.com
}

\begin{abstract}
Abstrak
Masyarakat di kawasan tepi sungai bagian pesisir sering mengalami krisis air bersih yang disebabkan oleh tingginya salinitas air tanah. Sebagai alternatif untuk mendapatkan air bersih, pada umumnya masyarakat menggunakan bahan baku air sungai yang keruh disaring dengan menggunakan kerikil dan pasir, namun hasilnya belum jernih. Cara mengatasinya adalah menggunakan teknologi tepat guna berupa pengolahan air dengan treatment koagulasi, filtrasi, absorbsi, dan pertukaran ion. Tujuan penerapan IPTEKS dalam program ini adalah; mengatasi masalah kesulitan penjernihan air sungai agar menghasilkan air hasil olahan menjadi jernih. Metode yang digunakan adalah ; sosialisasi, pelatihan serta managemen produk tentang pengolahan air sungai menggunakan "Water Treatment" untuk menghasilkan air bersih yang layak dikonsumsi. Teknologi yang diterapkan adalah sebagai berikut ; Bahan baku air sungai sebelum masuk bak pengolah dilakukan pretreatment dengan koagulan Poly Aluminium Chloride (PAC). Pada bak pengolah (I) dilakukan filtrasi, bak pengolah (II) treatment zeolit dan MGS, bak pengolah (III) berisi pasir silika dan resin sintetis. Air sungai yang keruh jika dilakukan pengolahan (treatment) menggunakan koagulan Poly Aluminium Chloride (PAC) dilanjutkan dengan filtrasi oleh filter spoon, kemudian absorben zeolit dan MGS, filter pasir silika dan diakhiri menggunakan resin sintetis kation dan resin sintetis anion dapat menghasilkan air yang jernih.
\end{abstract}

Kata kunci ; Absorbsi, Filtrasi, Koagulasi, Pertukaran Ion

\begin{abstract}
Riverside communities in coastal parts often have a clean water crisis caused by high salinity of groundwater. As an alternative to get clean water, in general, people use raw materials from turbid river water that is filtered by using gravel and sand, but the results are could not be clear. The solution is using appropriate technologies such as water treatment, treatment of coagulation, filtration, absorption, and ion exchange. The purpose of application of science and technology in this IbM program is; overcome the difficulties purification of river water in order to produce the processed water becomes clear. The method used is:socialization, training and products management of river water treatment using the "Water Treatment" to produce clean water suitable for consumption. The technology applied is as follows: Raw materials like river water before entering the processing tub performed pretreatment with coagulants Poly Aluminium Chloride (PAC). In the processing tub (I) made of filtration, processing tub (II) zeolite and MGS treatment, processing tub (III) contains silica sand and synthetic resins. Conclusion : The turbid river water when it is done processing (treatment) using a coagulant Poly Aluminium Chloride (PAC) followed by filtration by a filter spoon, then absorbent zeolites and MGS, silica sand filter and end use of synthetic resin synthetic resin cations and anions can produce clear water.
\end{abstract}

Keywords : Absorption, Filtration, Coagulation, Ion Exchange 
Setyo Purwoto, Teguh Purwanto, Luqmanul Hakim : Penjernihan Air Sungai Dengan Perlakuan Koagulasi, Filtrasi, Absorbsi dan Pertukaran Ion

\section{PENDAHULUAN}

Masyarakat di daerah tepi sungai Bengawan Solo bagian pesisir seperti Desa Tejoasri, Laren, Lamongan Jawa Timur mengalami kesulitan dalam hal kebutuhan air bersih, apalagi sebagai air minum. Hal ini disebabkan oleh tingginya salinitas air tanah (hingga $3000 \mathrm{ppm}$ ), dan parameter lain seperti $\mathrm{Na}^{+}=3500 \mathrm{ppm}, \mathrm{Mg}^{++}=278 \mathrm{ppm}, \mathrm{Ca}^{++}=$ $407 \mathrm{ppm}, \mathrm{Fe}$ (tot) $=0,088 \mathrm{ppm}, \mathrm{SO}_{4}^{-2}=350$ ppm, $\mathrm{CO}_{3}^{-2}=235 \mathrm{ppm}, \mathrm{pH}=$ sekitar 5,5 dan TDS $=3600 \mathrm{ppm}$ juga tidak memenuhi syarat sebagai air bersih. HIPPAM "TIRTAASRI" memiliki instalasi tandon air 10.600 Liter untuk didistribusi sebagai air kebutuhan sehari hari oleh penduduk warga desa setempat. Namun hasil treatment yang dilakukan hanya dengan cara menyaring menggunakan krikil tidak mampu menjernihkan air bahan baku yang berasal dari sungai Bengawan Solo (sangat keruh, salinitas dan TDS masih tinggi). Dengan keterbatasan ini, warga terpaksa mengkonsumsi air yang sangat keruh dan jauh dari "sehat", sehingga perlu adanya sentuhan teknologi untuk mengatasi hal tersebut, dan sangat mendesak. Rumusan masalah dalam penerapan IPTEKS ini adalah :

Mengatasi krisis air bersih dan bagi masyarakat dengan menggunakan teknologi tepat guna (TTG) berupa pengolahan air dengan treatment : koagulasi, filtrasi, absorbsi, dan pertukaran ion

Definisi :

1. Flitrasi merupakan proses pemisahan antara padatan atau koloid dengan cairan

2. Poly Aluminium Chloride (PAC) adalah bahan kimia berbentuk cairan bening kekuningan yang berfungsi sebagai sedimentasi dan penjernihan air.

3. Zeolit merupakan kristal alumina silika yang berstruktur tiga dimensi yang dapat dimanfaatkan untuk : filter, adsorben, ion-exchange, serta penurunan kesadahan dalam air.

4. Resin sintetis Bahan kimia dengan gugus fungsional organik tertentu yang dapat berfungsi sebagai penukar ion (IonExchanger) antara kation-anion dalam resin dengan anion-kation yang terdapat pada larutan yang diperlakukan.
Asumsi :

1) Pengoperasian teknologi tepat guna (TTG) ini telah disesuaikan dengan kondisi dan situasi

2) Dengan adanya TTG pengolahan air bersih sebagaimana penerapan IPTEKS ini, masyarakat dapat memperoleh air bersih untuk memenuhi kebutuhannya.

Lingkup penerapan IPTEKS : kelompok Karang Taruna, Perangkat Desa, Pihak PUSKESMAS

\section{Teknologi Penerapan IPTEKS}

Teknologi IPTEKS dalam penerapan ini merupakan teknologi tepat guna (TTG) berupa pengolahan air dengan tahapan : Bahan baku air sungai sebelum masuk pada bak pengolah dilakukan pretreatment menggunakan koagulan Poly Aluminium Chloride (PAC). Kemudian pada bak pengolah (I) dilakukan filtrasi, sedangkan pada bak pengolah (II) diberi perlakuan absorbsi menggunakan zeolit dan MGS. Langkah selanjutnya dilakukan pada bak pengolah (III) yang berisi pasir silika sebagai filtrasi dan resin sintetis sebagai penukar ion. Tujuan dari pada penerapan IPTEKS (IbM) ini adalah : mengatasi masalah kesulitan penjernihan air sungai agar menghasilkan air hasil olahan menjadi jernih.dengan metode memberi pengetahuan serta pelatihan tentang cara pengolahan air berbahan baku air sungai menggunakan bahan perlakuan Poly Aluminium Chloride (PAC), Filter spoon, MGS, Zeolit, Silika, Resin Anion, dan Resin Kation. Manfaat dari penerapan IPTEKS ini adalah untuk membantu mengatasi krisis air bersih bagi masyarakat di kawasan tepi sungai bagian pesisir yang sering mengalami krisis air bersih akibat tingginya salinitas air tanah

\section{METODE}

\section{Penerapan Ipteks (IbM)}

Penerapan IPTEKS (IbM) ini merupakan aplikasi perpaduan dari hasil penelitian dan pengabdian penulis, yaitu :

1) Desalinasi Air Payau Secara Ion Exchange dengan Treatment Resin Sintetis. (PDM-SPPH No.: 207/SP2H/ DP2M/III/2007)

2) Removal Salinitas Air Payau Secara Ion Exchange dengan Treatment 
Setyo Purwoto, Teguh Purwanto, Luqmanul Hakim : Penjernihan Air Sungai Dengan Perlakuan Koagulasi, Filtrasi, Absorbsi dan Pertukaran Ion

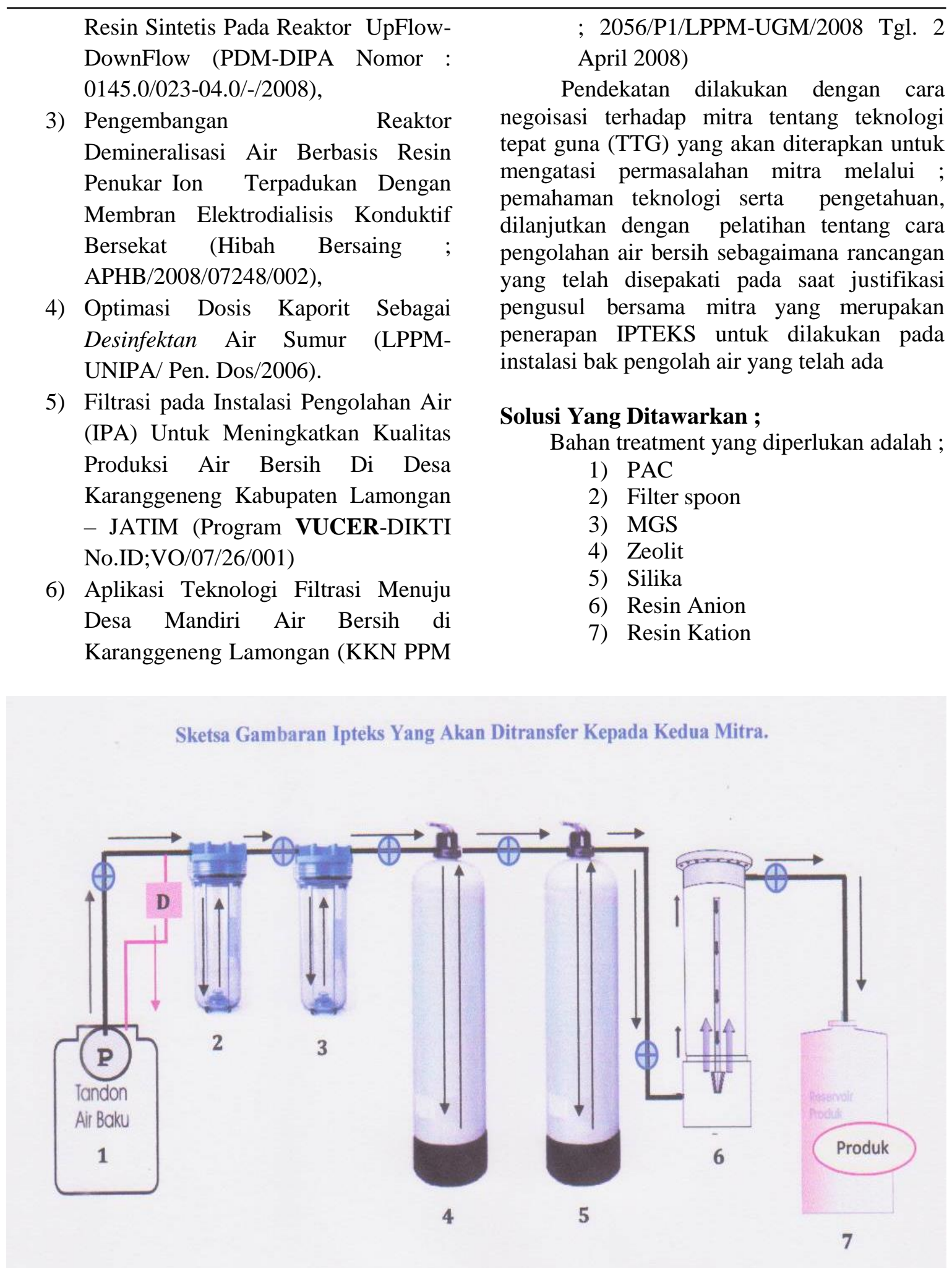

Gambar 1. Skema Treatment Pengolah Air Bersih Bahan Baku Air Sungai

\section{Alur proses skema treatment;}

Bahan baku air sungai (1) dipompa menuju pembubuhan Coagulant Aids Poly Aluminium Chloride (PAC) dengan konsentrasi sekitar 90 ppm sebagai proses koagulasi (2), kemudian dialirkan menuju treatment filter "Filter spoon" (3), dilanjutkan dengan Absorbsi Manganese Green Sand (4). Treatment dilanjutkan dengan Zeolit dan pasir silika (5), dilanjutkam dengan ion exchange 
Setyo Purwoto, Teguh Purwanto, Luqmanul Hakim : Penjernihan Air Sungai Dengan Perlakuan Koagulasi, Filtrasi, Absorbsi dan Pertukaran Ion

menggunakan resin sintetis kation anion (6). Sebagai air hasil olahan dipompa ke reservoir produk (7).

\section{Alur proses pelaksanaan ;}

Dalam pelaksanaannya, perlakuan disesuaikan dengan kondisi bak pengolah yang telah ada, yaitu perlakuan dengan tahapan ; sebelum masuk pada bak pengolah dilakukan pretreatment menggunakan koagulan Poly Aluminium Chloride (PAC). Kemudian pada bak pengolah (I) dilakukan filtrasi, sedangkan pada bak pengolah (II) diberi perlakuan absorbsi menggunakan zeolit dan MGS. Langkah selanjutnya dilakukan pada bak pengolah (III) yang berisi pasir silika sebagai filtrasi dan resin sintetis sebagai penukar ion.

Tabel 1. Spesifikasi Fungsi Alat Dan Bahan Yang digunakan

\begin{tabular}{|c|c|c|}
\hline Treatment & Fungsi & Keterangan \\
\hline Filtrasi & $\begin{array}{l}\text { pemisahan antara padatan atau } \\
\text { koloid dengan cairan }\end{array}$ & Filter busa (filter-spoon) \\
\hline $\begin{array}{l}\text { Poly Alumini } \\
\text { um Chloride } \\
\text { (PAC) }\end{array}$ & Sedimentasi, koagulasi & $\begin{array}{l}\text { merupakan proses pemisahan antara padatan atau } \\
\text { kolold dengan calran adalah bahan kimia } \\
\text { berbentuk calran bening kekunlngan yang } \\
\text { berfungsi sebagai sedimentasidan penjemlhan air. } \\
\text { Merupakan Cairan bening kekuningan } \\
\text { Dosis : } 30 \text { - } 80 \text { ppm } \\
\text { pH : } 3,5\end{array}$ \\
\hline $\begin{array}{l}\text { Coagulant Aids } \\
\text { Sucolite SP } 211\end{array}$ & Sedimentasi , koagulasi & $\begin{array}{l}\text { cairan tidak berwarna dan tidak berbau; } \mathrm{pH} \\
\text { pada suhu } 20^{\circ} \mathrm{C} \text { sebesar } 11-11,5 ; \text { berat jenis } \\
1,35 \mathrm{gr} / \mathrm{cm}^{3} . ; \mathrm{kadar} \mathrm{Al}_{2} \mathrm{O}_{3} \text { yaitu } 4,66 \% ; \mathrm{pH} \\
\text { larutan } 2 \%(\mathrm{pH} \text { soluble } 2 \% \text { di air } 33,553 ; \\
\text { bagian yang tidak larut dalam air } 0,060 \%\end{array}$ \\
\hline absorben Zeolit & $\begin{array}{l}\text { Absorbsi, filtrasi, ion } \\
\text { exchange, pelunakan } \\
\text { Menghilangkan kandungan } \\
\text { amoniak di dalam air sehingga } \\
\text { dapat menetralkan PH didalam } \\
\text { air. }\end{array}$ & $\begin{array}{l}\text { sebagai penukar kation (cation exchangers), } \\
\text { adsorben kesadahan atau pelunak air (water } \\
\text { softening), penyaring molekul (molecular } \\
\text { sieves), agen pendehidrasi, serta sebagai } \\
\text { bahan pengering (drying agents) } \\
\text { merupakan kristal alumina silika yang } \\
\text { berstruktur tiga dimensi yang dapat } \\
\text { dimanfaatkan untuk : filter, adsorben, ion- } \\
\text { exchange, serta penurunan kesadahan dalam } \\
\text { air. } \\
\text { Ukuran Volume pori : } 0,5 \mathrm{~cm} 3 \text { tiap cm3 } \\
\text { volume zeolit. } \\
\text { Densitas antara } 2,0-2,3 \mathrm{~g} / \mathrm{cm} 3\end{array}$ \\
\hline $\begin{array}{l}\text { Mangan Zeolit } \\
\text { (Greensand) }\end{array}$ & $\begin{array}{l}\text { Untuk menghilangkan } \\
\text { kandungan Mangan (Mn2+), } \\
\text { dan lapisan atas berminyak di } \\
\text { dalam air sebagai katalis dan } \\
\text { pada waktu yang bersamaan } \\
\text { besi dan mangan yang ada } \\
\text { dalam air teroksidasi menjadi } \\
\text { bentuk ferri-oksida dan } \\
\text { mangandioksida yang tak larut } \\
\text { dalam air }\end{array}$ & $\begin{array}{l}\text { Mangan-zeolite sebagai formulasi ; } \\
\left(\mathrm{K}_{2} \mathrm{Z} . \mathrm{MnO} \cdot \mathrm{Mn}_{2} \mathrm{O}_{7}\right) ; \text { Reaksi dari } \mathrm{Fe}^{2+} \text { dan } \mathrm{Mn}^{2+} \\
\text { dalam air dengan oksida mangan tinggi (higher } \\
\text { mangan oxide) menghasilkan filtrat yang } \\
\text { mengandung ferri-oksida dan mangan-dioksida } \\
\text { yang tak larut dalam air dan dapat dipisahkan } \\
\text { dengan pengendapan dan penyaringan }\end{array}$ \\
\hline Pasir Silika & $\begin{array}{l}\text { Menyaring kekeruhan yang } \\
\text { berasal dari lumpur, pasir, } \\
\text { endapan, dan partikel yang ada }\end{array}$ & \begin{tabular}{lllrr}
\multicolumn{4}{l}{ Pasir alami berwarna : Putih bening kekuningan } \\
Kekerasan & $\vdots$ & 7 & (skala & mohs) \\
Berat & jenis & $:$ & 2,65
\end{tabular} \\
\hline
\end{tabular}


Setyo Purwoto, Teguh Purwanto, Luqmanul Hakim : Penjernihan Air Sungai Dengan Perlakuan Koagulasi, Filtrasi, Absorbsi dan Pertukaran Ion

\begin{tabular}{|c|c|c|}
\hline Treatment & Fungsi & Keterangan \\
\hline & didalam air & $\begin{array}{llllr}\text { Titik lebur } & \text { : Kurang } & \text { lebih } & 1715 \quad \text { 0C } \\
\text { Bentuk } & \text { kristal } & : & \text { hexagonal } \\
\text { Panas } & \text { sfesifik } & : & 0,185\end{array}$ \\
\hline Resin anion & $\begin{array}{lr}\text { Demineralisasi } & \text { sebagai } \\
\text { Penukar anion } & \text { (penurunan } \\
\text { kation dalam air) } & \end{array}$ & $\begin{array}{l}\text { Dan panas konduktifitas : } 12-1000 \mathrm{C} \\
\text { Bahan kimia dengan gugus fungsional organlk } \\
\text { tertentu yang dapat berfungsi sebagai penukar } \\
\text { ion (/on-Exchanger) antara kation-anion dalam } \\
\text { resin dengan anion-katlonyang terdapat pada } \\
\text { larutan yang diperlakukan. } \\
\text { Butiran warna kuning }\end{array}$ \\
\hline Resin kation & $\begin{array}{lr}\text { Demineralisasi } & \text { sebagai } \\
\text { Penukar kation } & \text { (penu runan } \\
\text { anion dalam air) }\end{array}$ & $\begin{array}{l}\text { Bahan kimia dengan gugus fungsional organlk } \\
\text { tertentu yang dapat berfungsi sebagai penukar } \\
\text { ion (/on-Exchanger) antara kation-anion dalam } \\
\text { resin dengan anion-katlonyang terdapat pada } \\
\text { larutan yang diperlakukan. } \\
\text { Butiran warna kemerahan }\end{array}$ \\
\hline
\end{tabular}

Tabel 2. Alasan Dipilihnya Bahan Treatment Dalam Penerapan IPTEKS

\begin{tabular}{lll}
\hline No & \multicolumn{1}{c}{ Treatment } & \multicolumn{1}{c}{ Alasan pemilihan } \\
\hline A & filter-spoon & $\begin{array}{l}\text { Praktis, murah, mudah didapat, mudah dicuci, kemampuan filter } \\
\text { tinggi, mudah dibentuk. }\end{array}$ \\
B & Poly Alumini & Karena bentuknya cairan, maka akan lebih praktis dibanding dengan \\
& um Chloride (PAC) & Tawas, sedangkan kemampuan (daya) sedimentasi tidak jauh berbeda. \\
C & Zeolit \& & 1. Bebas lumpur dan endapan \\
& Mangan Zeolit (Greensand) & 2. Biaya cukup murah \\
& & 3. Bebas dari bahan kimia berbahaya pada efluennya \\
& & 4. Sederhana dalam pengoperasian \\
D & Resin anion (Lewatit Mono Plus & 5. Dapat menghasilkan air hingga zero kesadahan \\
& 1. Secara spesifik dapat melakukan penukaran anion dari air. \\
E & Resin kation Dowex HCR-S & 2. Lebih mudah dijumpai di pasaran. \\
& & 1. Secara spesifik dapat melakukan penukaran kation dari air. \\
F & Coagulant Aids Sucolite SP 211 & 2. Lebih mudah dijumpai di pasaran. \\
\hline
\end{tabular}

Kontrol ketepatan aliran serta masalah kesetimbangan massa berdasar pada proses penukaran ion, tetapi penekanannya pada proses pereaksiannya, yaitu system batch ataukah continuous. Resin sebagai ion exchange memang diakui sebagai desalinasi konvensional untuk air payau atau air laut, sekalipun dilakukan secara pabrikasi.

\section{Perhitungan Volume Resin}

Berdasarkan perhitungan kapasitas operasi yang berpedoman pada koefisien selektifitas, maka volume resin yang dibutuhkan dapat $\begin{array}{cc}\text { diturunkan } & \text { dari } \\ V=(Q \cdot t \cdot S) / C\end{array}$

\section{Dimana :}

$V=$ volume resin, $\mathrm{m} 3$

$Q=$ laju aliran, $\mathrm{m} 3 / \mathrm{h}$

$t=$ waktu operasi, $\mathrm{h}$

$C=$ kapasitas operasi resin, eq $/ \mathrm{m} 3$ resin

$S=$ "salinitas", total ion yang terserap resin, $\mathrm{eq} / \mathrm{m} 3$ air.

Selanjutnya kapasitas ion exchange biasanya dinyatakan dengan kapasitas total atau kapasitas operasi menurut formulasi berikut :

(Lee, 2005) 
Setyo Purwoto, Teguh Purwanto, Luqmanul Hakim : Penjernihan Air Sungai Dengan Perlakuan Koagulasi, Filtrasi, Absorbsi dan Pertukaran Ion

Tabel 3. Tipe Resin Penukar Ion Sintetik

\begin{tabular}{|c|c|c|c|c|c|}
\hline $\begin{array}{l}\text { Tipe } \\
\text { Resin }\end{array}$ & Grup fungsional & $\begin{array}{l}\text { Kerapatan } \\
\text { Kering } \\
\left(\mathrm{Kg} / \mathbf{m}^{3}\right)\end{array}$ & $\begin{array}{l}\text { pH } \\
\text { operasi }\end{array}$ & $\begin{array}{l}\text { Kapasi } \\
\text { tas } \\
(\mathrm{me} / \mathrm{ml})\end{array}$ & $\begin{array}{l}\text { Contoh merk } \\
\text { resin }\end{array}$ \\
\hline $\begin{array}{l}\text { Asam } \\
\text { kuat }\end{array}$ & $-\mathrm{SO}_{3}-\mathrm{H}^{+}$ & $790-850$ & $0-14$ & 2,0 & $\begin{array}{l}\text { Duolite C-20 } \\
\text { Amberlite } 120 \\
\text { Dowex } 50\end{array}$ \\
\hline $\begin{array}{l}\text { Asam } \\
\text { lemah }\end{array}$ & $-\mathrm{COO}^{-} \mathrm{H}^{+}$ & 720 & $7-14$ & 4,5 & $\begin{array}{l}\text { Duolite C-433 } \\
\text { Amberlite IRC-50 } \\
\text { Zeo Carb } 226\end{array}$ \\
\hline $\begin{array}{l}\text { Basa } \\
\text { kuat } \\
\text { tipe I }\end{array}$ & $\begin{array}{l}- \\
\mathrm{CH}_{2} \mathrm{~N}\left(\mathrm{CH}_{3}\right)_{3} \mathrm{OH}^{-}\end{array}$ & 720 & $0-14$ & 1,3 & $\begin{array}{l}\text { AmberliteIRA- } \\
\mathbf{4 1 0} \\
\text { Duolite A-101 D }\end{array}$ \\
\hline $\begin{array}{l}\text { Basa } \\
\text { kua } \\
\text { tipe II }\end{array}$ & $\begin{array}{l}- \\
\mathrm{CH}_{2} \mathrm{~N}\left(\mathrm{CH}_{3}\right)_{2} \mathrm{CH}_{2} \\
\mathrm{CH}_{2} \mathrm{OH}^{+} \mathrm{OH}^{-}\end{array}$ & 720 & $0-14$ & 1,4 & $\begin{array}{l}\text { Amberlite IRA- } \\
140 \\
\text { Duolite A-102 D }\end{array}$ \\
\hline $\begin{array}{l}\text { Basa } \\
\text { lemah }\end{array}$ & $-\mathrm{N}\left(\mathrm{CH}_{3}\right)_{2} \mathrm{H}^{+} \mathrm{OH}^{-}$ & 510 & $0-6$ & 2,5 & $\begin{array}{l}\text { Duolite A-7 } \\
\text { Amberlite IRA-93 }\end{array}$ \\
\hline
\end{tabular}

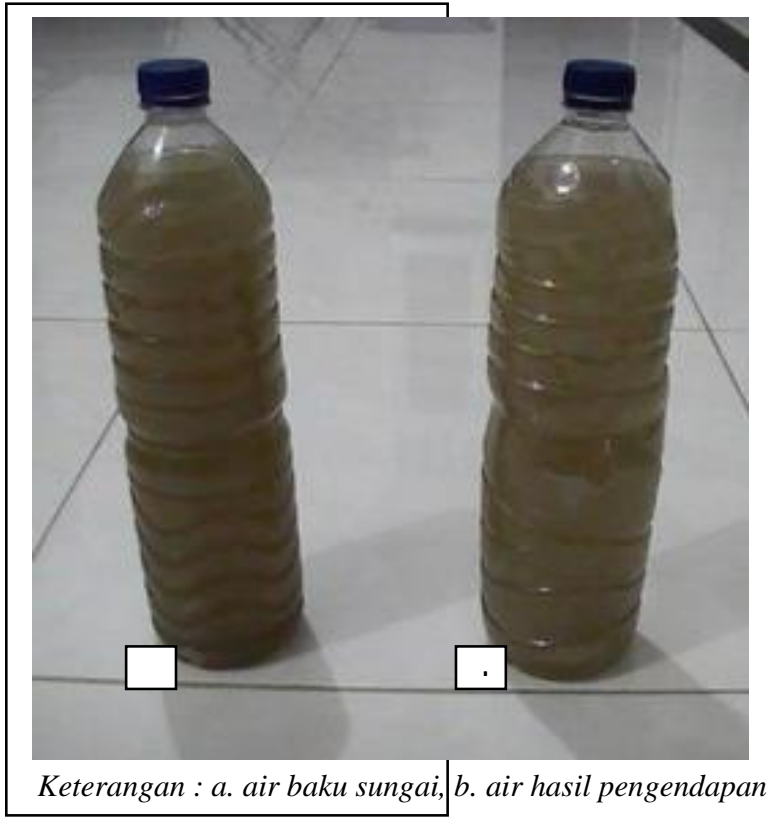

Gambar 2. Kondisi Hasil Pengolahan Sebelum Penerapan IBM

\section{HASIL DAN PEMBAHASAN}

Setelah dilakukan tahapan perlakuan pada pengolahan bahan baku air sungai dimana sebelum masuk pada bak pengolah dilakukan pretreatment menggunakan koagulan Poly Aluminium Chloride (PAC). Kemudian pada bak pengolah (I) dilakukan filtrasi, sedangkan pada bak pengolah (II) diberi perlakuan absorbsi menggunakan zeolit dan MGS. Langkah selanjutnya dilakukan pada bak pengolah (III) yang berisi pasir silika sebagai filtrasi dan resin sintetis sebagai penukar ion diperoleh hasil sebagaimana Gambar 3. 


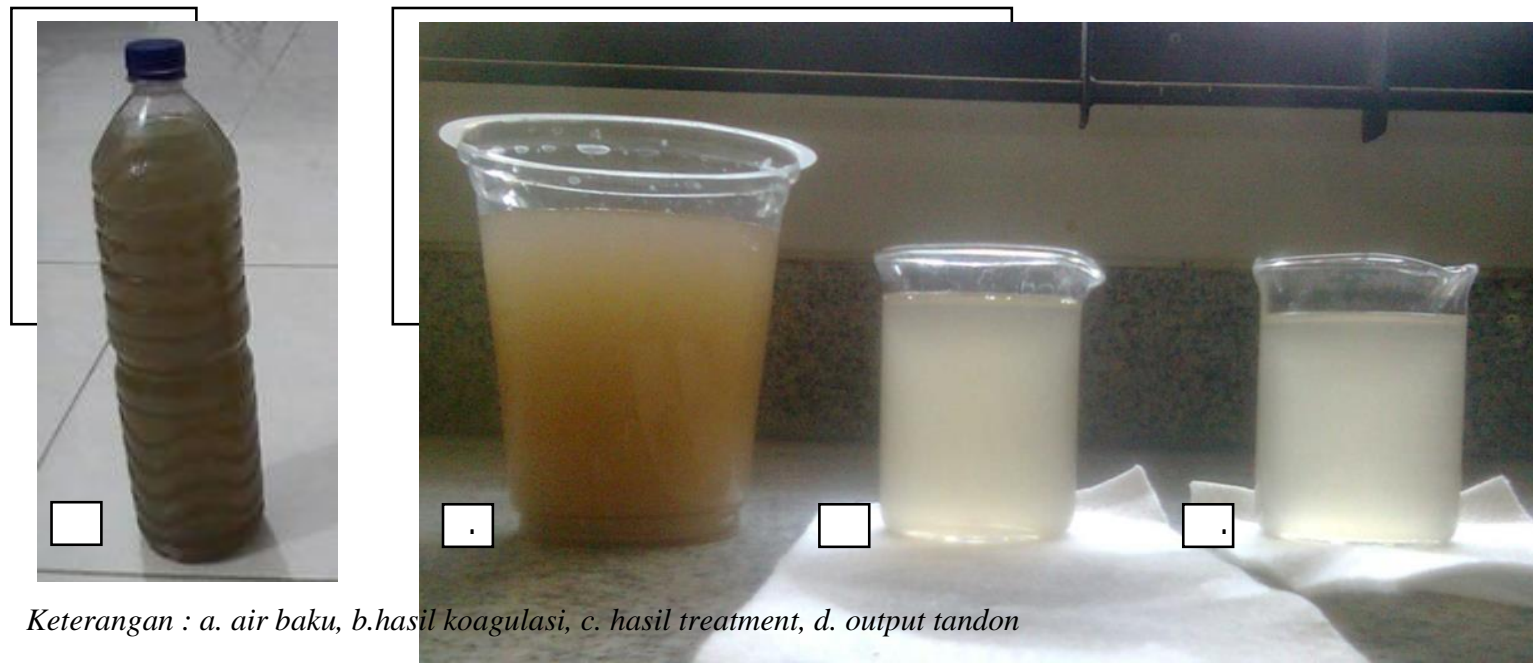

Gambar 3. Kondisi Hasil Pengolahan Setelah Penerapan IBM

Menurut Purwoto (2010), treatment Zeolith yang dijalankan dengan sistem aliran up-flow menggunakan time detention (td) 30 menit, kedalaman zeolit $60 \mathrm{~cm}$ dengan tujuan reduksi parameter air bersih didapatkan remove capacity: Kesadahan Total 185.72 ppm, Kalsiurn 100 ppm, Magnesium 85.72 ppm, Silika 25 ppm, Khlorida $52 \mathrm{ppm}$, Zat Padat Terlarut (TDS) $311 \mathrm{ppm}$, Besi 1.41 ppm, Mangan 0.46 ppm. Purwoto (2011), air dari genangan banjir diproses dengan treatment : filtrasi, kemudian dengan PAC, adsorben Zeolit, dilanjutkan dengan exchange resin kation dan exchange diteruskan ke resin anion, pembubuhan larutan kaporit serta absorbans menggunakan CA. mampu menurunkan parameter parameter: Warna $\quad 8.00$ TCU, TDS 142.00 ppm, Kekeruhan 4.80 NTU, Kesadahan Total 586.50 ppm, Kalsium Hardness 305.00 ppm, Magnesium Hardness 51.80 ppm, Klorida 69.00 ppm, e-Coli $3.00 \mathrm{sat} / 100 \mathrm{mI}$.

Media filter campuran dalam pengolahan air antara zeolit aktif dan karbon aktif (komposisi $75 \%$ zeolit aktif : $25 \%$ karbon aktif), dilanjutkan resin penukar kation dan anion mampu menurunkan kadar besi sebesar $67 \%$, kadar klorida $65 \%$ dan kadar TDS 63\%. (Nugroho at al. 2013). Penggunaan treatment Zeolit dan Manganese Green dilanjutkan dengan resin anion dan resin kation sebagai penukar ion yang terkandung dalam air payau diperoleh nilai penurunan parameter mineral menurut kriteria air bersih : Warna sebesar 10 Unit
PtCo, Kekeruhan 0.62 Skala NTU, TDS 128 $\mathrm{mg} / \mathrm{L}$, Total hardness $642.86 \mathrm{mg} / \mathrm{L} \mathrm{CaCO}$, Sulfat $57.35 \mathrm{mg} / \mathrm{L} \mathrm{SO} 4$, Nitrat $0.8 \mathrm{mg} / \mathrm{L}$ NO3$\mathrm{N}$, Nitrit $0.02 \mathrm{mg} / \mathrm{L}$ NO2-N, Amonia 0.99 $\mathrm{mg} / \mathrm{L} \mathrm{NH} 3-\mathrm{N}$, Besi $0.14 \mathrm{mg} / \mathrm{L} \mathrm{Fe}$, Seng 0.03 $\mathrm{mg} / \mathrm{L}$ Zn, Flourida $0.03 \mathrm{mg} / \mathrm{L}$ F, dan Deterjen $0.02 \mathrm{mg} / \mathrm{L}$. (Purwoto 2013).

Kombinasi treatment pengolahan air ; filtrasi menggunakan sediment poly propylene, absorbsi oleh carbon block dan manganese zeolite, ion exchange menggunakan resin anion dan resin kation kedalaman $70 \mathrm{~cm}$, dilanjutkan dengan Reverse Osmosis (RO) mampu menurunkan konsentrasi parameter menurut kriteria air bersih ; Total Disolved Solid (TDS) 2686 ppm, Kesadahan Total $371.43 \mathrm{mg} / \mathrm{L} \mathrm{CaCO} 3$, Klorida 1144 ppm, Coliform Total 4 MPN/100 mL, Kekeruhan 2.02 skala NTU, Warna 37 unit PtCo, Ammonia 1.35 ppm, Besi 0.18 ppm, Fluorida 0.46 ppm, Sodium 737.70 ppm, Zinc $0.08 \mathrm{ppm}$, Sulfat $24.56 \mathrm{ppm}$, dan Detergent $0.10 \mathrm{mg} / \mathrm{L}$ LAS. (Purwoto at al. 2014)

Perlakuan coagulant aid, filtrasi sediment polipropylena (SPP), manganese greensand, resin sintetik, dan membrane RO dapat meremoval parameter ; klorida sebanyak 2028 ppm, kekeruhan 2.74 skala NTU, warna 45 unit PtCo, besi $0.22 \mathrm{ppm}$, Total Disolved Solid (TDS) 3366 ppm, Total kesadahan $621.43 \mathrm{mg} / \mathrm{L}, \mathrm{CaCO} 3$, fluorida $0.62 \mathrm{ppm}$, Nitrate $0.06 \mathrm{ppm}$, Nitrite 0.64 , Zinc 0.08 ppm, Sulfat $40.46 \mathrm{ppm}$, dan Detergent at 0.12 mg/L LAS. (Nurhayati at al. 2014). Diantara ; 
Setyo Purwoto, Teguh Purwanto, Luqmanul Hakim : Penjernihan Air Sungai Dengan Perlakuan Koagulasi, Filtrasi, Absorbsi dan Pertukaran Ion

media zeolit alam, manganese green sand, dan zeolit yang teraktivasi dengan pemanasan, unt uk tujuan menurunkan Mn dan Total Coliform yang paling efektif adalah media filter manganese green sand, dimana penurunan kandungan $\mathrm{Mn}$ dari 2,53 mg/lt menjadi $<0,01 \mathrm{mg} / \mathrm{lt}$ sedangkan penurunan Total Coliform pada menit ke - 60 (Rachmah at al. 2014)

\section{Output}

1) Teratasinya masalah kesulitan penjernihan air sungai yang hanya disaring dengan menggunakan kerikil dan pasir menjadi lebih jernih.dengan cara perlakuan Poly Aluminium Chloride (PAC), Filter spoon, MGS, Zeolit, Silika, Resin Anion, dan Resin Kation

2) Terbukanya peluang untuk memperbesar debit olahan dengan cara penambahan unit bak pengolah baru

3) Peluang penerapan pengolahan air menggunakan teknologi tepat guna berupa pengolahan air dengan treatment koagulasi, filtrasi, absorbsi, dan pertukaran ion di lokasi lain.

\section{Outcome}

1) Bagi masyarakat di wilayah sasaran penerapan IPTEK akan memberikan solusi nyata berupa cara pengolahan air berbahan baku air sungai yang keruh menggunakan teknologi tepat guna berupa pengolahan air dengan treatment koagulasi, filtrasi, absorbsi, dan pertukaran ion.

2) Adanya peningkatan hasil usaha oleh mitra pengelola pengadaan air bersih untuk masyarakat Desa

3) Bagi Pemerintah merupakan jalan keluar (way out) dalam hal pemecahan masalah krisis air bersih di kawasan tepi sungai bagian pesisir.

\section{KESIMPULAN}

Air sungai yang keruh jika dilakukan pengolahan (treatment) menggunakan koagulan Poly Aluminium Chloride (PAC) dilanjutkan dengan filtrasi oleh filter spoon, kemudian absorben zeolit dan MGS, filter pasir silika dan diakhiri menggunakan resin sintetis kation dan resin sintetis anion dapat menghasilkan air yang jernih

\section{Ucapan Terima Kasih}

Ucapan terima kasih kepada Penanggungjawab kegiatan Pengabdian Kepada Masyarakat Direktorat Jenderal Pendidikan Tinggi, yang telah membiayai melalui Kopertis Wil 7 Jatim dengan nomor SPPH : 027/SP2H/PPM/K7/KM/2015 tanggal 2 April 2015.

\section{DAFTAR PUSTAKA}

Kanzaki, Y., Suzuki, N. (2001). "On the Selectivity of Ion Exchange Reaction." Journal of Ion Exchange 12(2-3): 57-66.

Lee, C. C., Lin, S.D. (2005). Handbook Of Environmental Engineering. Tokyo, McGraw-Hill Publishing.

Montgomery, J. M. (2005). Water Treatment Principles and Design. USA, Johan Weley Inc.

Nugroho, W., Purwoto, S. (2013). "Removal Klorida, TDS Dan Besi Pada Air Payau Melalui Penukar Ion Dan Filtrasi Campuran Zeolit Aktif Dengan Karbon Aktif." WAKTU, ISSN : 1412-1867, ed. Januari 2013 11(2): 47-59.

Nurhayati, I., Purwoto, S. (2014). "The Combination of Coagulant Aid, Ion Exchanger, and Reverse Osmosis (RO ) on Brackish Water Treatment." Journal of Natural Sciences Research, ISSN 2224-3186 (Paper); ISSN 2225-0921 (Online) 4(24): 26-30.

Purwoto, S. (2009). "Desalinasi Air Payau Secara Ion Exchange dengan Treatment Resin Sintetis." WAKTU ; ISSN : 1412-1867 Edisi Januari 2009 7(1): 52-59.

Purwoto, S. (2010). "Remove Capacity Treatment Zeolit Untuk Parameter Air Bersih." WAHANA; ISSN : 0853-4403, ed. Agustus 2010 55(2): 63-70.

Purwoto, S. (2011). "Reaktor Pengolah Air Bersih Iptek Bagi Masyarakat Untuk Daerah Rawan Banjir." WAKTU ; ISSN : 1412-1867; ed. Januari 2011 9(1): 1-7. 
Setyo Purwoto, Teguh Purwanto, Luqmanul Hakim : Penjernihan Air Sungai Dengan Perlakuan Koagulasi, Filtrasi, Absorbsi dan Pertukaran Ion

Purwoto, S. (2013). "Water Treatment Berbasis Zeolit Dan Ion Exchange Untuk Demineralisasi Air Payau." SEMINAR NASIONAL - Universitas PGRI Adi Buana Surabaya Pengembangan Teknologi Ramah Lingkungan Menuju Keberlanjutan Lingkungan Hidup (Makalah Sub Tema-2: TEKNIK): 157-167.

Purwoto, S., Sopandi, T., Kusuma, P.S.W., Nurcahyanie,W.D. (2014). "Removal Parameters of Clean Water using Treatment; Sediment Poly Propylene, Carbon Block, Manganese Zeolite, Ion Exchange, and Reverse Osmosis (RO)." Journal of Environment and Earth Science, ISSN 2224-3216 (Paper) ISSN 2225-0948 (Online) 4(23): 72-77.

Rachmah, N., Purwoto, S. (2014). "Efektifitas Penurunan Mn dan Total Coliform Pada Air Sumur Gali Berbasis Zeolit." WAKTU, ISSN : 1412-1867, ed. Januari 2014 12(1): 1-7.

Taffarel , S. R., Rubio, J., (2010). "Removal of Mn2+ from Aqueous Solution by Manganese Oxide Coated Zeolite." Minerals Engineering 23(14): 1131-1138.

Tan, V. (2007). "Upaya Pemanfaatan Air Payau Untuk Air Minum Suatu Study Kualitas Air Pada Perumahan Oma Indah Menganti - Gresik." ITS Library ,Civil Engineering RTS, Copyright @2003 